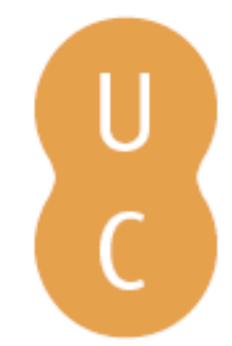

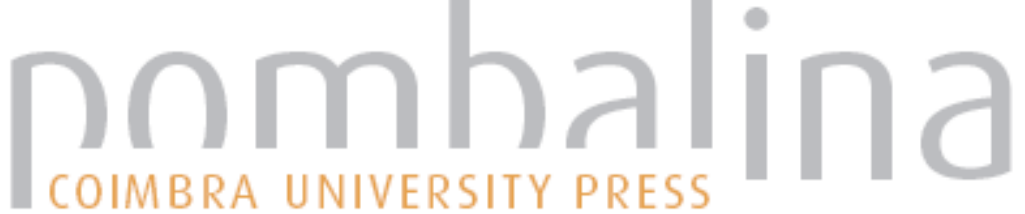

Notas sobre a mesa da Casa Real portuguesa no reinado de D. José I

Autor(es): $\quad$ Algranti, Leila Mezan

Publicado por: Imprensa da Universidade de Coimbra

URL

persistente:

URI:http://hdl.handle.net/10316.2/31582

DOI:

DOI:http://dx.doi.org/10.14195/978-989-26-0201-1_4

Accessed : $\quad$ 26-Apr-2023 13:03:43

A navegação consulta e descarregamento dos títulos inseridos nas Bibliotecas Digitais UC Digitalis, UC Pombalina e UC Impactum, pressupõem a aceitação plena e sem reservas dos Termos e Condições de Uso destas Bibliotecas Digitais, disponíveis em https://digitalis.uc.pt/pt-pt/termos.

Conforme exposto nos referidos Termos e Condições de Uso, o descarregamento de títulos de acesso restrito requer uma licença válida de autorização devendo o utilizador aceder ao(s) documento(s) a partir de um endereço de IP da instituição detentora da supramencionada licença.

Ao utilizador é apenas permitido o descarregamento para uso pessoal, pelo que o emprego do(s) título(s) descarregado(s) para outro fim, designadamente comercial, carece de autorização do respetivo autor ou editor da obra.

Na medida em que todas as obras da UC Digitalis se encontram protegidas pelo Código do Direito de Autor e Direitos Conexos e demais legislação aplicável, toda a cópia, parcial ou total, deste documento, nos casos em que é legalmente admitida, deverá conter ou fazer-se acompanhar por este aviso. 
Isabel dos Guimarães Sá Máximo García Fernández (directores)

\section{PORTAS ADENTRO comer, vestir, habitar} (ss. XVI-XIX) 


\title{
NOTAS SOBRE A MESA DA CASA REAL PORTUGUESA NO REINADO DE D. JOSÉ I
}

\author{
LeILA MeZan AlgRanti \\ IFCH ${ }^{1}$ \\ UNICAMP
}

Em 20 de setembro de 1765 o Secretário de Estado da Marinha e Ultramar, Francisco Xavier de Mendonça Furtado, informava ao responsável pela administração das Cozinhas e da Ucharia reais -o Conde de Redondo- que D. José I deveria chegar a Mafra em 30 de setembro e cear no mesmo dia na barraca edificada junto ao palácio ${ }^{2}$. Remetia em anexo uma ordem contendo a relação das pessoas que fariam parte da comitiva, bem como a forma como elas deveriam ser distribuídas nas diferentes mesas a serem montadas para as refeições. Talvez por se encontrar numa jornada e em momento de descontração, o monarca informava que desejava ter no primeiro lugar da «Mesa de Estado o gentil homem da câmara», que fazia às vezes de seu mordomo-mor ${ }^{3}$. Porém, nos demais lugares desta mesa informava:

${ }^{1}$ Professora Titular da disciplina de Historia do Brasil Colonial na Universidade Estadual de Campinas (Unicamp). A pesquisa realizada para a elaboração do presente estudo contou com o apoio da FCT, em especial ao projeto «Portas adentro» coordenado pela Professora dra. Isabel dos Guimarães Sá e do CNPq para o projeto de pesquisa sobre a História da alimentação na América portuguesa.

${ }^{2}$ D. Fernando de Sousa Coutinho (1716-1791), $12^{\circ}$ conde de Redondo, era o vedor -mor do rei e, a partir de 1765, passou acumular as funções de uchão, sendo responsável pela ucharia de D. José I. De acordo com o Padre Raphael Bluteau, ucharia é a casa onde se guardam as viandas ou despensa. Ver Vocabulario Portuguez e Latino on line: http://www.ieb.usp.br/online/index.asp

${ }^{3} \mathrm{O}$ mordomo-mor de D. José era Sebastião Carvalho de Melo, o conde de Oeiras e futuro marquês de Pombal, como se pode ler no decreto de 1765 o qual se encerra da seguinte maneira: «O conde de Oeiras, ministro/ secretário de Estado e meu lugar tenente no Real Erário que serve 
não deveria haver concurso, nem precedência alguma assentando-se cada um dos fidalgos que nela costuma comer, naturalmente e sem coisa que possa parecer cerimônia e só nos termos da civilidade que se pratica em qualquer mesa particular entre pessoas de tão distinta educação ${ }^{4}$.

Com essa breve instrução D. José flexibilizava o rígido protocolo de precedências que regulava as refeições da Casa Real, certo de que aqueles senhores partilhavam bem mais do que a comida e a bebida oferecidas. Naquele momento, além da fidelidade ao monarca, o que os unia era a convicção de ocuparem o topo da hierarquia social e política do Reino, fato que os distinguia dos demais indivíduos da sociedade. Além disso, esperava-se dos que se sentassem à mesa do rei, um «modo» de estar e de viver em sociedade que fazia da etiqueta a própria essência da vida na corte ${ }^{5}$. Ao que tudo indica, o monarca rompia com algumas convenções sociais na certeza de que outras seriam cumpridas. Estas, por sua vez, não precisavam ser lembradas pois, além de incorporadas às condutas da nobreza, encontravam-se presentes nos manuais de civilidade, obras estas bem conhecidas dos fidalgos que D. José I desejava ter à sua mesa na jornada a Mafra ${ }^{6}$.

Por outro lado, a conduta do rei deixava entrever que as refeições reais seguiam rituais distintos de acordo com a ocasião, podendo ser servidas com maior ou menor cerimônia, porém sempre com o cuidado de se preservar as hierarquias sociais, como se observa na lista que acompanhava o ofício de Mendonça Furtado. Esta informava, por exemplo, que o físico e o cirurgião mor da corte, assim como os confessores do rei, da rainha e de Suas Altezas, além dos demais médicos e cirurgiões presentes à jornada, deveriam compor «uma mesa»; o que equivale dizer, usufruir de um conjunto de iguarias e quantidade de pratos previstos para a posição que ocupavam na corte e, não necessariamente, que deveriam ser colocados fisicamente na mesma mesa ${ }^{7}$.

de meu mordomo-mor, o tenha assim entendido e faça executar pelo que lhe pertence. Palácio da Ajuda, 11 de maio de 1765. IAN/TT, Ministério do Reino livro 433, fl. 2 v.

${ }^{4}$ IAN/TT, Ministério do Reino, livro 433, fl. 32.

${ }^{5}$ Como esclareceu Norbert Elias, «Na sociedade de corte de antigo regime, a precisão no estabelecimento de um cerimonial, o rigor na definição dos gestos sujeitos à etiqueta, o cuidado com que o valor em prestígio de cada ato é ponderado, estão na medida da importância vital que se atribui à etiqueta e, de um modo geral, 'a maneira como as pessoas se tratam umas às outras». Ver A Sociedade de Corte, trad., Lisboa, Editorial Estampa, 1987, p. 76.

${ }^{6}$ Os tratados de civilidade tinham o objetivo pedagógico de expor em detalhes as regras de comportamentos sociáveis. Jacques Revel esclareceu que a ampla literatura de civilidade que proliferou na época moderna era produzida de acordo com o público que se visava atingir. Sobre o assunto ver Jacques Revel. «Os usos da civilidade», in Philippe Ariès e Roger Chartier $D a$ Renascença ao século das Luzes, trad. São Paulo, Companhia das Letras, 1991, pp. 170-171. Coleção História da Vida Privada dirigida por P.Ariès e G.Duby.

${ }^{7}$ Sobre a solenidade das refeições reais e os diferentes cerimoniais, ver a título de exemplo, Maria de los Ángeles Pérez Samper. «La Alimentación de las reinas en la España moderna», in 
Embora o documento não especifique os alimentos a serem oferecidos, esse fornece muitas outras informações sobre a vida social na corte e leva a supor se tratar de um evento que envolveria uma caçada, dada a presença de vários caçadores a receberem rações. Sugere ainda a complexidade da organização e o nível de detalhes envolvidos nos deslocamentos do rei. A fonte fornece, especialmente, informações sobre os membros da comitiva e seus ofícios como camareiros, porteiros, reposteiros, manteeiros, moços da prata, barraqueiros, capelão, boticários, além de criados particulares como cabeleireiros ou sapateiros. De acordo com o ofício de Mendonça Furtado, todos comeriam às custas da ucharia real e era isso que ele se apressava em comunicar ao vedor-mor de D. José para as devidas providências.

Tais informações, porém, não devem ter surpreendido o Conde de Redondo, pois desde maio daquele ano passara a acumular às atribuições de vedor-mor, as responsabilidades de inspeção da ucharia da Casa Real portuguesa. Tampouco a lista contendo a composição das mesas poderia lhe ter causado estranheza, pois tudo isso sempre fora matéria de regulamentação estrita. Afinal, etiqueta, normas de precedência e protocolos de todo gênero encontravam-se inexoravelmente vinculados à vida das cortes no Antigo Regime. A mesa da Casa Real portuguesa não constituía uma exceção. Ao contrário, o conjunto de normas que a regulava era extenso e reproduzia física e simbolicamente os valores e as diferenças sociais a serem preservados. Um exemplo típico desse detalhamento e do protocolo a ser seguido é o decreto de D. José I de 11 de maio de 1765 que dispôs sobre o funcionamento e novos procedimentos referentes à Ucharia real ${ }^{8}$.

Trata-se de um documento bastante significativo por permitir não apenas a reconstituição de certas práticas alimentares na corte de D. José e do universo material que as cercava, mas sobretudo por estimular a reflexão sobre as possibilidades que o estudo da alimentação oferece ao historiador para a compreensão da vida social, econômica e, por que não dizer, também política de uma comunidade. No caso desse decreto é possível perceber as necessidades que envolviam a mesa do dia a dia, a estrutura dos serviços e dos ofícios da Casa Real, as formas de sociabilidade, o exercício do poder e até mesmo a necessidade de tudo regular própria da sociedade de corte.

Embora alimentação seja bem mais do que simplesmente comida -pois comida seria aquilo que se ingere e alimentação todo o conjunto de práticas culturais e sociais que o ato de comer envolve- nosso objetivo neste trabalho é nos atermos a alguns aspectos referentes ao universo material da alimentação, presentes no novo decreto régio e cujos significados este estudo está longe de pre-

J. Martínez Millán, Maria Marçal Lourenço (coords). Las Relaciones Discretas entre las monarquias hispana y portuguesa: Las casas de las reinas (siglos XV-XIX) Madri, Ediciones Polifemo, 2008, p. 2016.

${ }^{8}$ IAN/TT, Ministério do Reino, livro 433, fl. 1 e sgts. 
tender esgotar. Entre as questões a serem comentadas destacam-se os produtos disponíveis, os tipos de alimentos consumidos, bem como alguns artefatos envolvidos nas refeições e no serviço de mesa dos diferentes membros da Casa Real. Mas antes de explorarmos esses domínios cabe compreendermos o teor do decreto de 1765 .

\section{NOVAS REGRAS NA UCHARIA E COZINHAS DA CASA REAL: O DECRE- TO DE 1765}

De acordo com o texto do próprio decreto, logo após o terremoto de 1755 , D. José passou a socorrer com rações de sua despensa muitas pessoas que não tinham essa prerrogativa por decreto ou qualquer outro regimento. O problema é que dez anos depois, o benefício continuava a ser distribuído e acabou por gerar abusos e irregularidades, o que o levou a baixar um decreto proibindo que continuassem a sair de sua ucharia e reais cozinhas qualquer ração ou produto com a referida finalidade ${ }^{9}$. No mesmo documento, para que as pessoas que tinham sido socorridas até então experimentassem «sua real benignidade», D. José estabeleceu que, enquanto ele o desejasse, receberiam do tesoureiro da Casa Real contrapartida em dinheiro para ajuda com alimentos. Instituía ainda que aqueles que antes do terremoto recebiam mantimentos na folha do tesoureiro poderiam escolher entre receber o auxílio em gêneros ou em dinheiro ${ }^{10}$.

Essa era apenas uma das medidas estabelecidas pelo novo decreto, o qual instituiu muitas mudanças administrativas, financeiras e de fiscalização nas cozinhas e na despensa do rei. Por meio deste recurso foram reformados com metade dos ordenados vários servidores da ucharia e da cozinha. Além disso, outros oficiais foram destituídos de seus cargos, embora novos postos tenham sido criados, como o cargo de tesoureiro particular da Real Ucharia ${ }^{11}$. Ainda no domínio administrativo foi aberta, a pedido do rei, uma devassa para se apurar os fatos relativos aos descaminhos de produtos, e inclusive, de um suposto complô em sua cozinha quando, em determinadas situações, alguns serviçais teriam dado a entender que a fazenda real estava falida e que não tinha recursos para comprar

${ }^{9}$ Ibidem, fl. 1.

${ }^{10}$ Seguem-se ao decreto as listas nominativas de todos aqueles que receberiam o benefício, bem como seu valor em ordem decrescente de acordo com a hierarquia social e ocupacional na corte. Por exemplo, à camareira-mor da rainha, marquesa aia e outras «donas» a seu serviço, o monarca mandava assistir com 30.000 réis por mês a cada uma por ajuda de custo. Outras donas da mesma câmara receberiam 20.000 réis «para ajuda do seu sustento» E assim por diante, até aqueles criados que receberiam 3000 réis como as engomadeiras, os moços de serviço de fora, os coveiros. Ver IAN/TT, Ministério do Reino, livro 433, Decreto de 1765, fls. 7v e 8.

${ }^{11}$ Ver Decreto de 1765, ob. cit., fl. 11. 
pão ou pagar os credores de Sua Majestade ${ }^{12}$. Devido a toda essa situação foram dispensados de suas funções o escrivão da cozinha, João Lucas de Barros, o comprador dela, alguns moços de compras e cozinheiros, ficando todos eles sujeitos a inquirições sobre os bens que dispunham antes e depois de ocuparem esses car$\operatorname{gos}^{13}$.

Enquanto não chegavam as informações desejadas, foram designadas sentinelas especiais para as dependências da cozinha e determinado que as receitas e despesas fossem colocadas por escrito. De acordo com o decreto, mudavam-se os procedimentos relativos aos pagamentos e criavam-se normas sobre onde e como comprar os mantimentos.

Assim, o decreto implantava uma série de procedimentos visando o controle, mas também economia frente às despesas, regulando praticamente tudo na despensa, na cozinha e nas mesas da Casa Real, como se pode ler no documento de 1765:

Proíbe Sua Majestade absolutamente que na sua cozinha despensas e oficinas delas entre pessoa alguma, que não seja das que se acharem no atual serviço delas. De tal sorte que havendo quem procure qualquer dos sobreditos, lhes devem estes vir falar for das cozinhas e dos lugares onde tiverem os seus respectivos exercícios, pelo menos na distância de trinta passos deles $^{14}$.

Com relação às medidas destinadas à ucharia, o decreto estabelecia uma série de normas relativas ao abastecimento de produtos frescos que não poderiam faltar na mesa real, como leite, ovos, natas, aves, peixes, verduras e frutas, indicando quem seriam os compradores responsáveis e as formas de pagamento. Buscava-se garantir a regularidade no fornecimento e o controle dos preços. Previa-se, por exemplo, que fossem selecionados estabelecimentos ou pessoas que garantissem a qualidade dos produtos e a honestidade nos pesos e medidas, devendo para isso haver sempre «balanças com todos os pesos grossos e miúdos que forem necessários». Para o controle das despesas criaram-se ainda os cargos de despenseiro - com quem ficariam as chaves e o cuidado da despensa- além de um moço de serviço a quem se atribuiu a responsabilidade pela arrumação dos gêneros que entrassem e saíssem da despensa. A tarefa das compras, por sua vez, foi atribuída a apenas um comprador, o qual deveria ser fixo e substituído ape-

${ }^{12}$ De acordo com o decreto de 1765 «consta que nos dias de Santa Emengrácia do presente ano quando estava maior número de fidalgos juntos nos quartos dos camaristas e vedores, se acharam todos sem pão para comer e se lhes mandou dizer da Cozinha e ucharia que não havia pão, nem dinheiro para se ir comprar.» Ver Decreto de 1765, op. cit., fl. 13.

${ }^{13}$ Ver Decreto de 1765, op. cit., fl. 13v. O monarca solicitou ainda que se procedesse ao exame das receitas e despesas que desde o terremoto teriam sido feitas na Ucharia; op. cit., fl. 15

${ }^{14}$ Ver Decreto de 1765, op. cit., fl. 25. 
nas em caso de doença. Concederam-lhe ajudantes, carro para transportar os produtos e até um jumento para o mesmo fim.

Com base no novo decreto, não é difícil imaginar a rotina de trabalho e o burburinho nas cozinhas reais com dezenas de pessoas trabalhando para alimentar uma verdadeira multidão de funcionários, fidalgos e a própria família real. No caso do comprador, este deveria comparecer diariamente ao mercado para escolher e providenciar a entrega dos produtos adquiridos. Quando se tratasse de grandes carregamentos, os mesmos deveriam ser remetidos por embarcações até as proximidades do palácio. Os fornecedores de mantimentos básicos como açúcar, manteiga, arroz, temperos, azeite e vinagres, no entanto, seriam selecionados pelo próprio conde de Redondo, «depois de haver conferido pelas amostras, as bondades e os preços dos gêneros» ${ }^{15}$.

O que mais chama a atenção no decreto em termos do abastecimento da despensa é a diversidade dos produtos mencionados que se encontravam à venda na cidade e seus arredores. Não restam dúvidas de que a mesa real e a dos membros da corte deveria se pautar pela fartura de alimentos, mas o que vale enfatizar é que havia, na época, uma produção capaz de garantir um tipo de consumo que não tinha a ver somente com paladares exigentes e bolsos opulentos, mas que se constituía em fator de identidade e diferenciação social. Como observou Daniel Roche, «nas antigas sociedades os modelos de consumo não eram apenas ligados às capacidades econômicas (...); todo um conjunto de regras estava fixado pelas situações sociais, cuja dinâmica apoiava-se ao mesmo tempo sobre a diferenciação e sobre a imitação» ${ }^{16}$. Com base no princípio das diferenças de consumo é que se organizava a distribuição dos alimentos entre as várias mesas da Casa Real, como se verá mais adiante. Era, porém, no espaço no qual se produzia a comida que tais diferenças eram postas primeiramente em prática. Em função disso, o decreto chamava a atenção para uma série de medidas voltadas para a cozinha, a maior parte visando à economia e os cuidados com possíveis desvios de produtos, como se observa no trecho abaixo:

A cozinha deve ser uma só e nela se deve cozinhar em um só vazio cada espécie de guisado que nela se preparar para todos os pratos das diferentes mesas. De sorte que, por exemplo, todas as peças de vaca das diferentes mesas sejam cozinhadas em uma só marmita, todos os fracasses, fricandós e mais guisados em uma só caçarola ${ }^{17}$.

Por outro lado, o mestre cozinheiro deveria calcular pesos e medidas, como por exemplo, «quanto de vaca e presunto precisava para cada prato de olha das

${ }^{15}$ Ver Decreto de 1765 , op. cit., fls. 25, 25v e 26.

${ }^{16}$ Daniel Roche, História das coisas banais - nascimento do consumo séc.XVII-XIX, Rio de Janeiro, Rocco, 2000, pp. 31-32.

${ }^{17}$ IAN/TT, Ministério do Reino, livro 433, fl. 26. 
diferentes mesas, quanto de carneiro para cada flamenga ou travessa de guisado». Os doces por sua vez, deveriam ser «comprados nos conventos onde melhor se fazem» ${ }^{18}$, o que sugere uma especialização e talvez até concorrência entre os vários estabelecimentos religiosos, a fim de servirem seus soberanos. Mas havia também doceiras no Paço, as quais, ao que parece, confeccionavam doces para a família real por encomenda e de acordo com o gosto particular de Suas Majestades $^{19}$.

Além das especificações sobre a forma de cozinhar, o decreto deliberava sobre o número de empregados na cozinha e seus respectivos salários, bem como sobre quem deveria ser o responsável por contratar, pagar e despedir toda essa gente, isto é, o conde de Redondo. Até os mimos e alimentos supérfluos para os membros da família real foram objeto de regulamentação e só seriam fornecidos pela ucharia ou pela cozinha se assinados pelas damas de câmara daqueles que os solicitavam. Quanto aos utensílios de mesa, estipulava o número de travessas, dúzias de pratos e copos para cada mesa e determinava o tipo de material das baixelas de acordo com o status social dos convivas: prata ou estanho ${ }^{20}$.

Todo esse aparato normativo culminava, no decreto de 1765 , na parte referente ao serviço de mesa, o qual dispunha sobre o número de mesas, quem ocuparia seus lugares e o que deveria ser oferecido em cada uma delas. Um olhar mais atento à distribuição das rações pode revelar algumas práticas alimentares na corte de D. José, além de sugerir aspectos interessantes sobre as relações sociais e de poder na Casa Real.

\section{A ORDEM DO SERVIÇO E AS DIFERENTES MESAS DA CASA REAL}

Numa época em que o abastecimento de víveres dependia basicamente das intempéries climáticas e que períodos de fome alternavam-se com escassos anos de abundância nas colheitas, comer na Europa, no século XVIII, podia ser antes de tudo uma questão de sobrevivência difícil de ser resolvida para a maior parte da população. Um grupo restrito da sociedade, porém, composto por indivíduos dos estamentos superiores e seus servidores, mesmo em épocas de carestia, sempre usufruiu de condições bastante favoráveis. É o caso dos membros da Casa Real portuguesa, cujo serviço de mesa o decreto de D. José procurava, entre outras medidas, regular. O documento é bastante original porque proporciona informações sobre as refeições ordinárias de diferentes membros da Casa Real, algo que foi bem menos notificado do que as refeições públicas e oficiais dos monarcas, manifestações estas de grande importância na vida de corte no Antigo

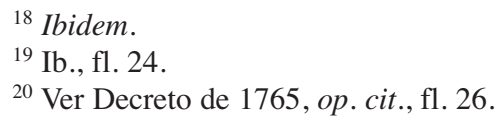


Regime $^{21}$. Em função disso, a maior parte dos registros sobre as mesas reais referem-se a banquetes celebrando a visita de embaixadores, casamentos de príncipes e outras situações extraordinárias que marcavam a vida social, religiosa e política de um reino. Isto porque, como observou Catherine Arminjon, a partir do século XVII e no XVIII, as grandes refeições reais atingiram um alto caráter de demonstração de prestígio e eram marcadas por um protocolo que testemunhava uma hierarquia extremamente sofisticada ${ }^{22}$.

Em certa medida, o decreto de D. José não deixava de ser uma espécie de protocolo ou roteiro para uso daqueles a quem cabia o serviço de mesa da Casa Real -desde o vedor-mor até o mais singelo ajudante de cozinha. Na mesma data, outro decreto régio expedido ao conde de Redondo complementava as novas ordens, mandando assistir a vários membros da Casa Real com valores em dinheiro «por ajuda de custo pela consignação das referidas cozinhas e ucharia $»^{23}$. Ao que tudo indica, tratava-se de dádiva ou mercê concedida em substituição às rações que o primeiro decreto extinguira.

Dois outros documentos acompanhavam as instruções ao Conde de Redondo: o primeiro intitulado «Tabela que havia na Ucharia Real» estipulava as porções de fruta, doces, azeite e vinho usadas até aquele momento para a distribuição dos alimentos. O segundo documento, «Tabela que havia na cozinha de Sua Majestade», continha informações sobre a dieta dos membros das diferentes mesas, tanto para os dias de carne como para os de peixe ${ }^{24}$. Os decretos e as mencionadas tabelas constituem as fontes por nós utilizadas na análise das práticas alimentares na corte de D. José.

De acordo com a «Tabela que havia na Cozinha de Sua Majestade» ficamos sabendo, por exemplo, que o serviço deveria ser feito seguindo-se rigorosamente a distribuição hierárquica de alimentos. (Vide tabela 1). Ou seja, quanto mais alto o posto ocupado e a importância das tarefas prestadas, maior a quantidade de comida oferecida, a qual se expressava em termos de número de iguarias ou de pratos. Assim, se o/a camarista e as damas da rainha eram contemplados com

${ }^{21}$ Para um estudo sobre a mesa real portuguesa em momentos de menor cerimônia ver Maria José Azevedo Santos, Jantar e cear na corte de D. João III, leitura, transcrição e estudo de dois livros da cozinha do rei, Vila do Conde, Câmara Municipal de Vila do Conde, 2002.

${ }^{22}$ Catherine Arminjon; Beatrix Saule «Introduction», in Table Royales et Festins de Cour en Europe 1661-1789, Actes Du colooque international, Palais des Congrés, Versailles, 1994, La Documentation Française, Ecole Du Louvre, Paris, 2004, pp. 15-16. Além dos relatos de viajantes, outras fontes históricas bastante significativas sobre a mesa dos reis ou das elites são os inventários de bens, os livros de receitas e despesas e os protocolos preparados para as mais diversas cerimônias na corte.

${ }^{23}$ IAN/TT, Ministério do Reino, livro 433, fl. 3.

${ }^{24}$ Trata-se de listagens contendo dados sobre a distribuição de alimentos, as quais permitiram a montagem de algumas tabelas a fim de se ter uma idéia mais clara sobre a alimentação dos diferentes grupos sociais que compunham a Casa Real. Ver IAN/TT, Ministério do Reino, livro 433, Tabela que havia na Ucharia Real e Tabela que havia na Cozinha de Sua Majestade, fls.16-20v. 
cinco iguarias ao jantar e três à ceia, aqueles que ocupavam os cargos imediatamente abaixo, como guarda-roupas, açafatas, médico, porteiro da câmara, estribeiro-menor, guarda-damas e confessores receberiam uma iguaria a menos tanto no almoço quanto na ceia. Com relação às demais mesas, em escala decrescente, o número de pratos acompanhava a hierarquia do serviço prestado à Casa Real: as moças do retrete seriam contempladas, nos dias de carne, com «sopa e olha, uma galinha assada/e uma propina de massa ao jantar», recebendo nas refeições noturnas «um guisado e uma franga assada», enquanto as moças do quarto e a porteira, à exceção da galinha assada, teriam as mesmas prerrogativas. À noite, porém, cabia-lhes «somente uma iguaria».

TABELA 1.

NÚMERO E CONTEÚDO DOS PRATOS SERVIDOS NAS REFEIÇÕES DAS PESSOAS DO SERVIÇO DA CASA REAL ANTES DE 1765

\begin{tabular}{|c|c|c|c|c|}
\hline Cargo/função & $\begin{array}{l}\text { Dia de carne jantar } \\
\mathrm{N}^{\circ} \text { iguarias gdes } \\
\text { e pequenas }\end{array}$ & Ceia & $\begin{array}{l}\text { Dia peixe jantar } \\
\mathrm{N}^{\circ} \text { iguarias gdes } \\
\text { e pequenas }\end{array}$ & Ceia \\
\hline Camarista & $5 \mathrm{gds}$ e $2 \mathrm{pq}$ & $3 \mathrm{gd} \mathrm{e} 2 \mathrm{pq}$ & $4 \mathrm{gd} \mathrm{e} 5 \mathrm{pq}$ & $3 \mathrm{gd} \mathrm{e} 4 \mathrm{pq}$ \\
\hline Damas & $5 \mathrm{gds}$ & $3 \mathrm{gd} \mathrm{e} 2 \mathrm{pq}$ & $5 \mathrm{gd}$ & $4 \mathrm{gd}$ \\
\hline Guarda-roupa & $4 \mathrm{gds}$ & 2 & 4 & $3 \mathrm{gd}$ \\
\hline Açafatas & $4 \mathrm{gds}$ & 2 & 4 e 5 pratnh pq & 3 \\
\hline Médico & $4 \mathrm{gds}$ & 2 & $3 g d$ e3pratnh & 2gd e3pratnh \\
\hline \multicolumn{5}{|l|}{ Porteiro de } \\
\hline Câmara. & $4 \mathrm{gds}$ & 2 & 4 & 3 \\
\hline Estribeiro-mor & $4 \mathrm{gds}$ & 2 & 4 & 3 \\
\hline Guarda-damas & $4 \mathrm{gds}$ & 2 & 4 & 3 \\
\hline Confessores & $4 \mathrm{gds}$ & 2 & 4 & 3 \\
\hline Moças do retrete & $\begin{array}{l}\text { Sopa e olha, } \\
\text { 1 galinha } \\
\text { Assada, propina } \\
\text { de massa }\end{array}$ & $\begin{array}{l}1 \text { guisado e } 1 \\
\text { franga assada }\end{array}$ & 3 & 2 \\
\hline $\begin{array}{l}\text { Moças de quarto } \\
\text { e porteira }\end{array}$ & $\begin{array}{l}\text { Sopa e olha } 1 \\
\text { propina d massa }\end{array}$ & 1 & 3 & 2 \\
\hline Porteiro da & Sopa e olha 1 & 1 guisado e 1 & 3 & 2 \\
\hline Câmara. & galinha assada & franga assada & & \\
\hline Os particulares & $\begin{array}{l}\text { Sopa e olha e } 1 \\
\text { galinha assada }\end{array}$ & $\begin{array}{l}1 \text { gal e bocado } \\
\text { guarnição }\end{array}$ & 3 & 2 \\
\hline $\begin{array}{l}\text { Ajudantes de } \\
\text { câmara }\end{array}$ & $\begin{array}{l}\text { Sopa e olha e } 1 \\
\text { galinha assada }\end{array}$ & $\begin{array}{l}1 \text { gal e bocado } \\
\text { guarnição }\end{array}$ & 3 & 2 \\
\hline Reposteiros & Sopa e olha & 1 prato & 2 & 2 \\
\hline Varredores & Sopa e olha & 1 prato & 2 & 2 \\
\hline Moços mantearia & Sopa e olha & 1 prato & 2 & 2 \\
\hline Moços da prata & Sopa e olha & 1 prato & 2 & 2 \\
\hline Porteiros & Sopa e olha & 1 prato & 2 & 2 \\
\hline Cavalhariças & 3 pratos & 2 pratos & 2 & 2 \\
\hline
\end{tabular}

Fonte: IAN/TT, Ministério do Reino, livro 433, Tabela que havia na Cozinha de sua Majestade fols $17 \mathrm{v}-20 \mathrm{v}$. 
A variedade e as quantidades de alimentos oferecidos aos membros da Casa Real estavam sujeitas ainda a dois outros princípios: horário das refeições e calendário religioso. Observa-se nos documentos disponíveis que a dieta à noite era mais leve em todas as mesas, reduzindo-se pelo menos um prato em relação à refeição do meio-dia. Nos dias de jejum eclesiástico, além da esperada substituição de peixe por carne, oferecia-se uma iguaria a menos do que nos dias de carne em ambas as refeições ${ }^{25}$. A exemplo do que sucedia em vários países católicos da época, seriam possíveis dispensas da prática do jejum. Em 1768, por exemplo, foi publicado um Edital de Sua Eminência em que declara que no Patriarcado de Lisboa é permitido o uso de ovos e lacticínios na Quaresma, medida que foi endossada no mesmo ano pela câmara ${ }^{26}$.

As mudanças introduzidas em 1765 por D. José na ucharia e cozinha reais, contudo, não alteraram o princípio geral existente em relação ao serviço de mesa e à distribuição de alimentos para as diversas mesas de sua Casa, isto é: a hierarquia dos cargos. (Vide tabela 2 ). $\mathrm{O}$ que pode ter sofrido alguma alteração é a posição de um ou outro servidor na escala social da corte, resultando em mudanças em seu regime alimentar. Um exemplo desse tipo seria o caso do médico da corte o qual, após o decreto, passou a usufruir de uma iguaria a mais ao jantar (quatro ao invés de três) mantendo, porém, os dois pratos anteriormente determinados para a ceia. Também receberiam quatro pratos à refeição principal os dois moços do guarda-roupa do rei e do príncipe, «os dois criados particulares que entrarem de guarda a Sua Majestade e ao sereníssimo infante D. Pedro» e o cirurgião de serviço ${ }^{27}$. Os porteiros da cana, os reposteiros do rei e da rainha, assim como os dois varredores dos quartos do monarca e do infante foram contemplados com três pratos ao jantar e um à ceia. Quanto aos cozinheiros do monarca, estes teriam ração semelhante aos criados particulares, sinal de suas responsabilidades, mas também da consideração usufruída. Os dois ajudantes e os oito moços de cozinha tinham, certamente, direito a uma boa ração (igual a dos porteiros de cana), «contanto que nenhum dos sobreditos possa extrair coisa alguma para fora da cozinha contra a disposição do real decreto de sua majestade» ${ }^{28}$. Mas o decreto de 1765 era mais detalhado do que a lista existente na cozi-

${ }^{25} \mathrm{O}$ jejum eclesiástico consistia na «abstinência de todo gênero de carne e em se comer uma só vez ao dia, e na hora costumada pela Igreja em determinados dias ou períodos do ano». Ver D. Sebastião Monteiro da Vide, Constituições Primeiras do Arcebispado da Bahia, São Paulo, Antônio Louzada Antunes, 1852 (1707), Livro Segundo, tit. XVI, parágrafo 394, pp. 157-158.

${ }^{26}$ Ver Coleção da Legislação Portuguesa, Lisboa, 1829, p. 1768, APUD Ana Marques Pereira, ob. cit., p.67. Com relação às dispensas do jejum eclesiástico ver meu estudo: Leila Mezan Algranti, «Dias gordos e dias magros: calendário religioso e práticas alimentares cristãs na América portuguesa Setecentista», apresentado no Colóquio Internacional Constituições Primeiras do Arcebispado da Bahia 300 anos - Universidade Federal da Bahia, 09/2007 (no prelo).

${ }^{27}$ IAN/TT, Ministério do Reino, livro 433, fl. 22v.

${ }^{28}$ Ibidem, fl. 23. 
nha, pois dava as coordenadas da mesa do rei, da rainha e de seus filhos, algo que a anterior não fornecia, como se verá mais adiante.

TABELA 2.

COMPOSIÇÃO E SERVIÇO DAS MESAS DA CASA REAL A PARTIR DE 1765

\begin{tabular}{|c|c|c|c|c|}
\hline $\begin{array}{l}\text { Componentes } \\
\text { das mesas }\end{array}$ & Jantar $n^{\circ}$ pratos & Tipos de pratos & Ceia $n^{\circ}$ pratos & Tipos de pratos \\
\hline Reais pessoas & $\begin{array}{l}\text { (8 da cozinha } \\
\text { principal) }\end{array}$ & $\begin{array}{l}\text { há uma cozinha } \\
\text { particular }\end{array}$ & 4 & \\
\hline $\begin{array}{l}\text { Princesa e } \\
\text { infante D. Pedro }\end{array}$ & $\begin{array}{l}3 \text { maiores de } \\
\text { sopa, vaca e arroz }\end{array}$ & $\begin{array}{l}\text { Ditas flamengas } \\
\text { c/guisados, } \\
2 \text { c/assados e } 1 \\
\text { massa }\end{array}$ & 6 flamengas & \\
\hline Príncipe & $\begin{array}{l}\text { Não tem idade } \\
\text { p/por mesa }\end{array}$ & $\begin{array}{l}\text { Pratinhos para } \\
\text { seus anos }\end{array}$ & & \\
\hline Infantas & $\begin{array}{l}3 \text { pratos: sopa } \\
\text { vaca e arroz }\end{array}$ & $\begin{array}{l}2 \text { flamengas } \\
\text { c/guisados, } \\
2 \text { c/assados; } \\
1 \text { massa }\end{array}$ & 6 flamengas & $\begin{array}{l}\text { c/guisados, } \\
\text { assados e saladas }\end{array}$ \\
\hline $\begin{array}{l}\text { vedor da CR e } \\
\text { da rainha gentis } \\
\text { homens da } \\
\text { câmara do Rei } \\
\text { e do Infante }\end{array}$ & $\begin{array}{l}\text { Duas cobertas } \\
1^{\mathrm{a}}: \mathrm{c} / 7 \text { pratos }\end{array}$ & $\begin{array}{l}3 \text { pratos maiores } \\
\text { de sopa, vaca e } \\
\text { arroz na fileira } \\
\text { do meio; } 2 \\
\text { entradas; } 2 \\
\text { guisados mais } \\
\text { ligeiros nos } \\
4 \text { ângulos } \\
\text { 2) } 2 \text { pratos gd } \\
\text { de assados, } \\
1 \text { massa no meio; } \\
4 \text { flamengas de } \\
\text { entremeios nos } \\
4 \text { ângulos }\end{array}$ & $\begin{array}{l}1 \text { coberta } \\
\text { c/ } 7 \text { pratos }\end{array}$ & \\
\hline $\begin{array}{l}\text { Criados da } \\
\text { mesa acima }\end{array}$ & $\begin{array}{l}\text { Todos os pratos } \\
\text { a benefício de } \\
\text { seus criados }\end{array}$ & & & \\
\hline $\begin{array}{l}2 \text { moços de } \\
\text { guarda-roupa } \\
\text { do rei e do ppe } \\
\text { infante }\end{array}$ & 4 pratos & $\begin{array}{l}\text { Sopa, vaca, arroz, } \\
1 \text { assado }\end{array}$ & $\begin{array}{l}2 \text { pratos (todos } \\
\text { da medida q.vai } \\
\text { referida) }\end{array}$ & \\
\hline médico & 4 pratos & $\begin{array}{l}\text { sopa, vaca, arroz } \\
\text { assado ou guisado }\end{array}$ & 2 pratos & \\
\hline $\begin{array}{l}2 \text { criados do rei } \\
\text { e do infante e o } \\
\text { cirurgião }\end{array}$ & 4 pratos & $\begin{array}{l}\text { Sopa, vaca, arroz, } \\
\text { e } 1 \text { assado }\end{array}$ & 2 pratos & $\begin{array}{l}\text { Ou de guisado e } \\
\text { arroz ou assado e } \\
\text { salada }\end{array}$ \\
\hline $\begin{array}{l}2 \text { reposteiros do } \\
\text { rei e rainha }\end{array}$ & 3 pratos & Sopa, vaca, arroz & 1 prato & \\
\hline
\end{tabular}




\begin{tabular}{|c|c|c|c|c|}
\hline $\begin{array}{l}2 \text { varredores } \\
2 \text { porteiros } \\
\text { quartos } \\
\text { do rei e do } \\
\text { infante }\end{array}$ & 3 pratos & Sopa, vaca, arroz & 1 prato & \\
\hline Cozinheiros & 4 pratos & $\begin{array}{l}\text { Sopa, arroz, vaca, } \\
1 \text { assado }\end{array}$ & 2 pratos & $\begin{array}{l}\text { Guisadoc/arroz } \\
\text { ou assado } \\
\text { c/salada* }\end{array}$ \\
\hline $\begin{array}{l}2 \text { ajudantes e } \\
8 \text { moços de } \\
\text { cozinha }\end{array}$ & 3 pratos & $\begin{array}{l}\text { Sopa,arroz, vaca } \\
1 \text { assado }\end{array}$ & 1 prato & $\begin{array}{l}\text { Guisado ou } \\
\text { assado }\end{array}$ \\
\hline
\end{tabular}

A mudança mais significativa introduzida pelo decreto quanto à distribuição de comida para os membros da Casa Real foi a já mencionada oferta de contrapartida em dinheiro para aqueles excluídos do benefício das rações. Afinal, era esse tipo de abuso que o mesmo pretendia corrigir. $\mathrm{O}$ valor atribuído, contudo, seguia sendo estabelecido com base no mesmo principio hierárquico dos ofícios. Assim, com relação aos membros da Casa da rainha, observa-se que a marquesa camareira-mor e a marquesa aia da rainha e outras damas de elevada condição social passariam a receber cada uma, trinta mil réis por mês para ajuda de custo com alimentos. As damas e açafatas, por sua vez, teriam vinte mil réis, enquanto as moças de retrete, as porteiras e as criadas dos quartos poderiam contar com oito mil réis ${ }^{29}$.

Na corte de D. José, portanto, comida continuava sendo objeto de mercê quer fosse sob a forma de alimentos, quer de numerário. Este sentido de dádiva se manifestava de muitas formas podendo ser visto como distinção, caridade ou benignidade do monarca, de acordo com cada situação. Como bem esclareceu Natalie Davis, a dádiva era mais do que uma mera oferta ou um ato de generosidade. Era uma transação cordial de amizade na qual o retorno se tornava explícito e a gratidão de Deus ou do próximo era esperada. Enfim, uma forma de troca na qual a reciprocidade mútua e a gratuidade poderiam também se impor ${ }^{30}$. E é isto exatamente o que se observa no decreto de 1765 , no qual D. José, ao invés de excluir a mercê de alimento, instituída informalmente após o terremoto, passou a normatizar a forma de concedê-la: gêneros ou dinheiro. O Decreto torna evidente que o problema não era ofertar comida, bens ou qualquer outra coisa,

${ }^{29} \mathrm{Ib}$., fl. 3.

${ }^{30}$ Sobre o sistema de dádiva na época moderna ver Natalie Zemon Davis, The Gift in Sixteenth- century France, Madison, The University of Wisconsin Press, 2000. 
mas sim o desregramento, a falta de controle e a possibilidade de facilitar o furto ou a indisciplina de seus súditos. Eram condutas desse tipo que o monarca visava corrigir e prevenir, o que leva a concluir que o decreto foi mais uma das medidas reformadoras implantadas ao longo do reinado de D. José por seu valido, o marquês de Pombal ${ }^{31}$.

Se o sistema de dádiva, ou o «gift mode»-como denominou Natalie Davisera parte constitutiva dos valores que regiam a sociedade do Antigo Regime, e D. José, assim como outros soberanos valeram-se dele em situações múltiplas no exercício do poder, a cortesia e a civilidade eram indispensáveis no trato social entre os membros da corte. Nesse sentido as normas de comportamento, designadas como «normas de cortesia», definiam um modo de ser e de estar em sociedade. Desde a Idade Média e mais precisamente a partir do início da época moderna, com as iniciativas de Erasmo de Roterdã e Baltazar Castiglione, o gênero da literatura de civilidade se sedimentou, ampliando-se com sucessivas e variadas edições ao longo dos séculos XVII e XVIII ${ }^{32}$. Tais obras tinham como propósito o controle dos gestos e dos corpos, e, nesse sentido, os modos à mesa e a forma de servir as refeições adquiriram significado social de destaque. Em função disso os manuais de civilidade e etiqueta passaram a dedicar atenção ao serviço de mesa.

Ainda que o objetivo do decreto de 1765 não tenha sido explicitamente o de estabelecer um protocolo do serviço de mesa, pode-se extrair desse documento e daqueles que o acompanhavam algumas informações a este respeito. A denominação de iguarias grandes e pequenas, por exemplo, que aparece na lista de distribuição de alimentos anterior ao decreto, sugere que o serviço de mesa era à francesa, isto é, com as travessas dispostas na mesa simetricamente a cada serviço ou coberta. O mesmo se observa na mesa dos vedores do rei e da rainha, bem como dos gentis homens, a partir de 1765 , pois o decreto informava que estes senhores teriam direito a duas cobertas com sete pratos na hora do jantar e uma coberta com o mesmo número de pratos à ceia: a primeira coberta ou serviço deveria conter três pratos maiores de sopa, vaca e arroz na fileira do meio; duas flamengas de entradas; duas de guisados mais ligeiros nos quatro ângulos da

${ }^{31}$ Sobre o reinado de D. José I ver Nuno Gonçalo Monteiro, D. José, Lisboa, Círculo dos Leitores, 2006.

${ }^{32} \mathrm{O}$ livro de Baltazar Castiglione, O Cortesão, de 1527 e A civilidade Pueril de Desidereo Erasmo datada de 1530, assim como $O$ Galateo de Giovanni della Casa publicado em 1558, são considerados os tratados de civilidade mais influentes do século XVI. De acordo com Jorge Arditi, $O$ Cortesão não era apenas um tratado de boas maneiras, mas um livro sofisticado e que transmitia valores estéticos e morais, no qual o sentido de «graça» recebe um sentido alargado, compreendendo simultaneamente um significado comportamental, moral e político-social. A graça seria a propriedade essencial de um habitante das cortes. Ver Jorge Arditi A Genealogy of Manners - Transformation of Social Relations in France and England from the Fourteenth to the Eighteenth century, Chicago-Londres, University of Chicago Press, 1998, pp. 101-103. 
mesa. Segunda coberta: dois pratos grandes de assados, 1 massa no meio; quatro flamengas de entremeios nos quatro ângulos ${ }^{33}$.

Entende-se, portanto, que haveria dois serviços completos, devendo a mesa do jantar ser «coberta» com iguarias duas vezes, contendo pratos grandes e pratinhos, conforme estipulava o serviço francês. À ceia, apenas uma coberta com vários pratos seria servida. Como o decreto determinou à parte quais seriam as quantidades de fruta e de doces oferecidas em cada mesa, infere-se que poderia haver um terceiro e último serviço dedicado às sobremesas ${ }^{34}$. Outra opção seria oferecer os doces e as frutas na segunda coberta. Como não se dispõem de menus propriamente ditos, mas de indicações do que deveria ser servido, é difícil determinar a ordem do serviço. Segundo Jean-Louis Flandrin, o estudo dos menus dos séculos XVII e XVIII apontou que o mais comum era não haver mais do que três serviços numa refeição. O importante é ter claro que a ordem dos serviços numa refeição, assim como seus conteúdos mudaram sensivelmente entre os séculos XVII e XIX e até mesmo de uma refeição a outra numa mesma época ${ }^{35}$.

No livro de cozinha de Domingos Rodrigues, primeira obra do gênero publicada em Portugal que atingiu muitas edições até o final do século XVIII e, portanto, ainda estava em voga no reinado de D. José I, o famoso cozinheiro de D. Pedro II propôs cardápios para vários banquetes. Nesses, predominavam as refeições com três cobertas, cabendo aos doces e frutas lugar na terceira coberta, identificados nos últimos pratos (oitavo e nono). Ou seja, não haveria uma coberta exclusiva para sobremesas ${ }^{36}$. No cerimonial do duque de Bacchi, embaixador francês recebido com grande pompa em 1753, usaram-se três cobertas seguidas de uma quarta, composta apenas de doces. A mesa de doces para esta ocasião foi montada numa sala à parte, com aparato semelhante ao das demais cobertas ${ }^{37}$. Não era raro oferecerem-se também pratos doces como entremeios nas diferentes cobertas ${ }^{38}$.

${ }^{33}$ IAN/TT, Ministério do Reino, livro 433, decreto de 11 de maio de 1765, fl. 22.

${ }^{34}$ Ibidem, fl. 24.

${ }^{35}$ Jean-Louis Flandrin, L'Ordre des mets, Paris, Editions Odile Jacob, 2002, p.15.

${ }^{36}$ Domingos Rodrigues, Arte de Cozinha, Lisboa, Imprensa Nacional - Casa da Moeda, 1987, pp. 168-170 ( $1^{\mathrm{a}}$ ed. 1680). Cem anos depois foi publicado o segundo livro de cozinha em Portugal, do cozinheiro francês Lucas Rigaud, intitulado Nova Arte de Cozinha que criticava a maneira de cozinhar de Rodrigues e pretendia introduzir um novo conceito de culinária em Portugal.

${ }^{37}$ Ver Ana Marques Pereira, Mesa Real, Lisboa, Edições INAPA, 2007 p. 58. Desde que o açúcar conquistou as cortes renascentistas, o serviço de açúcar separou-se paulatinamente e passou a ser um acontecimento particular como esclareceu Roy Strong. O autor descreve festividades em vários locais da Europa, nas quais a mesa de doces surpreendeu os convivas, quer em salas separadas, quer constituindo o centro das atenções em uma refeição solene. Ver sobre as «refeições de açúcar» Roy Strong. Banquete - uma história ilustrada da culinária, dos costumes e da fartura à mesa, Rio de Janeiro, Zahar Editor, 2004, pp. 167-173.

${ }^{38}$ De acordo com o glossário presente no primeiro livro de cozinha publicado no Brasil, o qual é uma compilação das receitas contidas nos livros de Domingos Rodrigues e de Lucas Rigaud, 
Atente-se, porém, que de acordo com o decreto, a doçaria parece ser um privilégio das mesas de pessoas mais graduadas, pois além dos membros da família real, apenas os vedores e gentis homens das Casas do rei e da rainha receberiam algum tipo de doce.

Para as demais mesas designava-se um prato de fruta e nada mais ${ }^{39}$. Embora a sobremesa possa parecer algo supérfluo na dieta comum e digno de mesas reais, era muito difundida em Portugal, havendo uma doçaria profissional desde o século XVI, conforme indicam os estatutos das confrarias de pasteleiros e confeiteiros de Lisboa, desde essa época ${ }^{40}$. Tão afamado se tornou no Reino esse

TABELA 3.

DISTRIBUIÇÃO DE FRUTA E DOCES AOS MEMBROS DA CASA REAL DE ACORDO COM O DECRETO DE 1765

\begin{tabular}{cc}
\hline Reis & $\begin{array}{c}\text { Não querem doce algum além do q mandam } \\
\text { fazer pelas conserveiras do interior do paço e } \\
\text { condessa de fruta conforme o tempo der. }\end{array}$ \\
\hline $\begin{array}{c}\text { Princesa NS e sereníssimo senhor infante } \\
\text { D. Pedro }\end{array}$ & Idem \\
Príncipe Nosso Senhor & Não deve haver doce \\
Infantas & 2 pratos fruta+ 1 prato de doce ou coberto de \\
calda
\end{tabular}

Fonte: IAN/TT, Ministério do Reino, livro 433 Papel que sua Majestade manda baixar para se regularem as mesas da Sua Real Casa e o serviço delas, fols 24

entremeios «são preparados que acompanham os pratos principais». Ver anônimo, $O$ Cozinheiro Imperial (1849), São Paulo, Editora Nova Cultura, 1996, p. 197. Para mais informações sobre esses três livros de cozinha ver Leila Mezan Algranti «Os livros de receitas e a transmissão da arte luso-brasileira de fazer doces (séculos XVII-XIX)», in Actas do III Seminário Internacional sobre a História do Açúcar - O açúcar e o cotidiano, Funchal, Secretaria Regional do turismo - Cultura Centro de Estudos de História do Atlântico, 2004, pp. 127-143.

${ }^{39}$ Ver Decreto de D. José, op. cit., p. 24.

${ }^{40} \mathrm{O}$ Regulamento dos Confeiteiros, de final de 1575, fixava as regras de confecção e venda de seus produtos feitos com mel ou açúcar nas ruas de Lisboa. Ver Regulamento dos /confeiteiros de Lisboa,apud, Carlos Consiglieri e Marilia Abel, A Tradição Conventual na doçaria de Lisboa, Sintra, Colares Editora, 1999, p. 21. 
segmento da alimentação que acabou por tornar conhecidas as habilidades doceiras das freiras de certos conventos femininos. Alfredo Saramago, analisando a doçaria conventual alentejana, fornece várias receitas tradicionais de doces que trazem no nome a identificação de seus conventos: pastéis de Santa Clara; bolo do paraíso (convento do Paraíso das dominicas), encharcada alentejana das monjas de Santo Agostinho, cavacas de Santa Catarina, broinhas de São José ${ }^{41}$.

O ritual de mesa na corte josefina envolvia, porém, mais do que travessas contendo uma variedade de alimentos. Como lembrou Ana Marques Pereira, a sala de jantar como espaço próprio para as refeições surgiu apenas no século XVIII, sendo, portanto, algo relativamente recente na corte portuguesa. Antes a mesa era móvel, podendo ser armada em qualquer lugar ${ }^{42}$. Na economia dos comportamentos à mesa, o uso de talheres já estava incorporado nessa época, bem como a regulamentação sobre suas funções como esclareceram Marchesi e Vercelloni, lembrando-nos que a utilização do garfo individual levou algum tempo para se fixar, sobretudo fora da Itália, onde não raro ainda se comia com a ajuda de um pedaço de pão ${ }^{43}$. De qualquer modo, é certo que entre os séculos XVII- XVIII uma organização de mesa foi criada e viu-se então se instalar o lugar dos pratos, o uso da colher e do guardanapo. Gestos antigos como cortar o pão com a mão, por a mão no prato comum foram substituídos pelo uso individual dos talheres ${ }^{44}$.

Com relação ao serviço de mesa, o decreto de D. José indicava ainda que havia duas cozinhas -uma geral e outra particular para a família real-e que o rei comia muitas vezes privada e separadamente da rainha. As comidas públicas, por sua vez, eram reservadas para os dias festivos. Nessas ocasiões especial atenção era posta não apenas no que seria servido, mas no aspecto decorativo da mesa e na imagem de espetáculo que tais cerimônias demandavam. Às normas de comportamento individual, juntavam-se os móveis e os utensílios luxuosos como as toalhas de renda, os copos de cristal e as baixelas confeccionadas em prata. Destas últimas, a mais famosa do período, foi certamente aquela encomendada em 1756, após o terremoto, a François Thomas Germain ${ }^{45}$. Consta que já se encontrava confeccionada grande parte dela em 1765, quando da falência do

${ }^{41}$ Ver Alfredo Saramago, Doçaria Conventual do Alentejo - as receitas e o seu enquadramento histórico, Sintra, Colares Editora, 2000, pp.65-94. Sobre a importância da doçaria nalimentação no império português ver Leila Mezan Algranti «A hierarquia social e a doçaria luso-brasileira (séculos XVII ao XIX)», in Revista da Sociedade Brasileira de Pesquisa Histórica, Curitiba, n. 22, 2002, pp. 27-47.

${ }^{42}$ Ana Marques Pereira, ob. cit., p. 13.

${ }^{43}$ Gualtiero Marchesi e Luca Vercelloni, La Tavola Imbandita - storia estética della cucina, Bari, Laterza, 2001, p. 33.

${ }^{44}$ Ver Daniel Roche, ob. cit., p. 313.

45 Sobre o assunto ver Isabel da Silveira Godinho (org) A Baixela de sua Majestade Fidelíssima, Lisboa, IPAR, 2002. 
conhecido prateiro. No entanto, não há referências de seu uso no reinado de D. José e a inauguração oficial foi geralmente atribuída às bodas de D. Maria. Outras baixelas de prata ficaram famosas no período, como aquela que pertenceu ao duque de Aveiro e foi confiscada junto com os demais bens quando de sua prisão $0^{46}$. Mas o esplendor da baixela Germain, projetada para quatro cobertas, contendo pratos, travessas com tampas, sopeiras, recipientes para olha, cestos de pão, saleiros, molheiras, galheteiros, salvas para doce, jarras, bules, talheres, e tantas outras peças, garantiu-lhe grande atenção, não só na época, mas posteriormente também ${ }^{47}$.

Antes de atentarmos para o que continham essas ricas baixelas de prata, vale observar que através dos nomes e dos cargos daqueles que receberiam alimentos no decreto régio é possível identificar alguns dos departamentos da estrutura doméstica da Casa Real; era uma estrutura interna complexa, com grande número de criados para atenderem às necessidades do monarca e de sua família, como chamou a atenção Mafalda Soares da Cunha. Indica ainda «os problemas de gerenciamento que o funcionamento dessa estrutura acarretavam, desde a seleção para o provimento dos cargos e funções e as remunerações devidas, ao controle e fiscalização das tarefas, altamente especializadas ${ }^{48}$.

Tendo por base as dependências indicadas por Mafalda Soares que proviam às necessidades básicas do corpo e do espírito no serviço palatino de Vila Viçosa nos séculos XVI e XVII, bem como sua observação de que esse modelo organizativo dos Braganças era semelhante ao da maior parte das casas reais européias, destacam-se no documento analisado alguns setores de serviço tais como: guarda-roupa, mesa, estrebaria, fazenda, físicos, caça e músicos ${ }^{49}$. O setor para o qual é possível obter mais informações sobre os cargos e seu funcionamento, é certamente aquele ligado à alimentação tanto na parte referente ao abastecimento (ucharia), quanto à confecção dos alimentos (cozinha). No século XVIII, de acordo com David Alexandre Felismino, a ucharia «contava com uma estrutura e um funcionamento bem definidos, experimentados durante quatro séculos» ${ }^{50}$. Estava sob a direção do vedor que, por sua vez, se comunicava com os responsáveis de cada setor e articulava as diferentes atividades. Ainda segundo o mesmo autor,

\footnotetext{
${ }^{46}$ Ver Ana Marques Pereira, ob. cit., pp. 63-64.

${ }^{47}$ Sobre o cerimonial de mesa em Portugal e a baixela Germain ver Leonor d'Orey «Le cérémonial et les usages de table à La cour du Portugal», in Catherine Arminjon e Béatrix Saule (org) Tables Royales et festin de cour em Europe, op. cit., pp. 315-329.

${ }^{48}$ Mafalda Soares da Cunha, A casa de Bragança 1560-1640 práticas senhoriais e redes clientelares, Lisboa, Editorial Estampa, 2000.

${ }^{49}$ Sobre a organização do espaço doméstico e os diversos departamentos do paço ducal de Vila Viçosa no século XVII ver Mafalda Soares da Cunha, op. cit., p. 99 e 101 a 102.

${ }^{50}$ David Alexandre Felismino. «As Ucharias da Casa Real portuguesa (1706-177) alimentar, servir e representar o rei», in J. Martínez Millán, Maria Paula Marçal Lourenço ob. cit., 2008, p. 418.
} 
cabia ao vedor a supervisão de duas cozinhas: a particular do monarca, príncipes e infantes e a principal ${ }^{51}$.

A rainha, como se percebe pelo documento de 1765, possuía casa separada, a qual tinha seu próprio pessoal de serviço, mas «a despesa do comestível dependia da Casa Real, sendo os ordenados e rações dos servidores pagos pela Casa dos consortes» ${ }^{52}$. Quanto ao número de funcionários, serviam nessa época na ucharia e na cozinha particular do rei: «1 comprador, 5 moços da ucharia, 9 moços de compras, 26 cozinheiros e 17 ajudantes ${ }^{53}$. Cada um deles tinha sob a sua responsabilidade um dos elos desse importante segmento da organização doméstica na qual se constituía a casa Real: a alimentação dos monarcas, seus familiares, fidalgos e funcionários.

\section{DO FOGÃO À MESA REAL: COMIDAS DO DIA-A-DIA}

A alimentação é um importante componente da vida cotidiana, quer devido às atividades reproduzidas diariamente destinadas à sua preparação, quer aos rituais de consumo necessários à sobrevivência. Embora não se possa saber se as mudanças instituídas pelo decreto de 1765 foram de fato aplicadas, o documento oferece algumas informações sobre os produtos e os tipos de alimentos que poderiam ser utilizados na preparação das refeições de indivíduos de diferentes segmentos sociais, bem como as quantidades consideradas adequadas. Se hoje é difícil avaliar de que forma ocorria na prática o consumo, as listas contendo a esperada distribuição dos alimentos podem indicar as representações da sociedade sobre os mesmos.

A preocupação, por exemplo, em se regular por decreto a quantidade de pão destinada aos membros da Casa Real confirma sua importância na dieta alimentar da época, assim como sugere diferenças no seu consumo de acordo com a faixa etária, o gênero e a ocupação das pessoas. Por outro lado, se os membros da família real deveriam receber menos pão do que os vedores régios é possível imaginar que haveria outros produtos em abundância à sua disposição e até mesmo que essas quantidades tivessem utilidades diferentes nas referidas mesas.

${ }^{51}$ Ibidem, p. 419.

${ }^{52} \mathrm{Ib}$. Como apontou David Felismino, era bastante complexa a estrutura dos ofícios nas cozinhas e ucharia reais e a documentação não permite sua total compreensão. No entanto, o autor fornece uma excelente e detalhada visão dos diferentes cargos e remuneração com base nas folhas de pagamento. Ver sobre o assunto «As Ucharias da Casa Real portuguesa (1706-1777)», op. cit., pp. 422-424.

${ }^{53}$ Ver «Decreto da Reforma dos Cozinheiros, ajudantes, moços de compras e Relação adjunta» maio de 1765, AN/TT, Casa Real, livro 104, fls. 35r-35v, citado por David Felismino, op . cit., p. 420. 
TABELA 4.

RAÇÕES DE PÃO DISTRIBUÍDAS ÀS MESAS DOS MEMBROS DA CASA REAL DE ACORDO COM O DECRETO DE 1765

\begin{tabular}{cc}
\hline Cargos e funções & Pão \\
Reis & 200 reis \\
Princesa e infante & 200 réis \\
Príncipe & 1 tostão \\
Infantas & 300 reis \\
Vedor, gentis-homens da câmara; vedor da casa & 480 reis \\
da rainha & 120 reis \\
2 moços do guarda -roupa & 60 reis para cada dia \\
\hline
\end{tabular}

Fonte: IAN/TT, Ministério do Reino, livro 433 Papel que sua Majestade manda baixar para se regularem as mesas da Sua Real Casa e o serviço delas, fol. $23 \mathrm{v}$

A maior ou menor quantidade dos produtos distinguia os indivíduos, conforme foi visto, mas seu significado não foi sempre o mesmo. Na Idade Média, como assinalou Massimo Montanari, os poderosos se definiam em primeiro lugar como grandes comedores e precisavam comer muito; com o passar dos séculos, o tema da quantidade de alimentos como função de poder e de prestígio social evoluiu diversamente. $\mathrm{O}$ importante não será apenas consumir mais alimentos do que os outros comensais, mas ter mais comida à disposição para poder oferecer aos companheiros, hóspedes, servos e cães ${ }^{54}$. De qualquer modo, como lembra o mesmo autor, «a formalização das quantidades não exclui o comer muito como atributo das classes dominantes». Esse princípio da comensalidade e da boa mesa evidencia-se na corte de D. José, como apontado na tabela 4 que indica as quantidades de pão para as diferentes mesas. $\mathrm{O}$ mesmo sucede na tabela 2 , na qual se observam as quantidades dos pratos de carne, outro produto básico da alimentação da época, haja vista sua presença em todas as mesas da Casa Real. A esses produtos somavam-se o vinho, o azeite, as frutas, os legumes; todos esses ingredientes eram indispensáveis para a elaboração de uma refeição farta, sendo que os membros da casa da rainha os recebiam na forma de rações diárias, antes de 1765, como se pode observar na tabela 5 .

${ }^{54}$ Ver sobre as quantidades de alimentos e as mudanças de seus significados ao longo dos séculos Massimo Montanari Il cibo come cultura, Bari, Laterza, 2004, pp. 90-91 e 93. 
TABELA 5.

DISTRIBUIÇÃO DE PRODUTOS DA UCHARIA REAL ÀS PESSOAS A SERVIÇO DA RAINHA ANTES DE 1765

\begin{tabular}{|c|c|c|c|c|c|c|c|}
\hline Cargo/função & $\begin{array}{l}\text { Pão } \\
\text { Réis }\end{array}$ & $\begin{array}{l}\text { Quartilho } \\
\text { azeite }\end{array}$ & Fruta & $\begin{array}{l}\text { Doce } \\
\text { arratel }\end{array}$ & $\begin{array}{l}\text { Vinho } \\
\text { Canadá }\end{array}$ & Açúcar & chá \\
\hline $1^{\mathrm{a}}$ camarista & 300 & $11 / 2$ & 1 & 1 & 1 & em pó & - \\
\hline Vedores & 300 & $11 / 2$ & 1 & 1 & 1 & em pó & - \\
\hline 1.g.-roupa & 60 & 1 & 1 & $1 / 2$ & - & - & - \\
\hline $\begin{array}{l}\text { Porteiro câmara } \\
\text { da rainha }\end{array}$ & 60 & 1 & 1 & $1 / 2$ & - & - & - \\
\hline Camareira-mor & 100 & $1 / 2$ & 1 & 1 & - & - & - \\
\hline $1^{\mathrm{a}}$ dama & 80 & $1 / 2$ & Fruta & $1 / 2$ & & & \\
\hline Guarda damas & 40 & - & 1 & $1 / 2$ & $1 / 2$ & - & - \\
\hline Confessor & 80 & - & Fruta & $1 / 2$ & $1 / 2$ & & \\
\hline Médico & 80 & $1 / 2$ & 1 & 1 & - & em pó & chá \\
\hline $1^{\mathrm{a}}$ moça retrete & 40 & $1 / 2$ & & & & & \\
\hline $\begin{array}{l}\text { Moça quarto, } \\
\text { reposteiro, } \\
\text { varredor, moços } \\
\text { da prata e da } \\
\text { mantearia }\end{array}$ & 40 & - & - & - & - & - & \\
\hline Porteiro da cana. & 40 & & Fruta & & & & \\
\hline D. Lucas & 60 & - & Fruta & $1 / 2$ & & & \\
\hline Fr. José & 40 & & Fruta & $1 / 2$ & & & \\
\hline
\end{tabular}

Fonte: IAN/TT, Ministério do Reino, livro 433, Tabela que havia na ucharia real fols.16-17v

Esta lista de produtos que estava disponível na ucharia de D. José é interessante porque alarga nossa visão sobre as práticas alimentares da época ao contemplar tipos distintos de alimentos. De um lado, regulava produtos básicos como pão e vinho, este último ofertado apenas para os segmentos mais privilegiados; de outro, indicava produtos complementares na dieta como o azeite, usado para temperar, pois se cozinhava geralmente com «manteiga de vaca», «manteiga de porco» ou toucinho ${ }^{55}$. Os demais produtos como as frutas, os doces, o açúcar e até o chá, talvez possam ser considerados em certa medida supérfluos, o que indica que seriam um benefício a mais usufruído pelos membros da casa da rainha e uma forma de retribuição por serviços prestados, amizade ou gratidão ${ }^{56}$.

${ }^{55}$ Sobre as gorduras utilizadas na época para fritar, refogar e cozinhar ver Domingos Rodrigues, op. cit., pp. 52, 71 e 72.

${ }^{56}$ Com relação às quantidades presentes no documento disponível na ucharia de D. José, cabe esclarecer que uma canada seria o equivalente a 2 litros ou 4 quartilhos; 2 quartilhos compunham 
De todos os produtos ou alimentos mencionados, o pão e a carne eram os elementos centrais na composição de uma refeição, o que é confirmado nas tabelas apresentadas nesse estudo por meio de sua frequiência e quantidades. O pão, embora não tenha sido especificado, seria confeccionado com farinha de trigo, pois quanto mais branco, mais caro e mais valorizado. È provável, portanto, que o pão servido na Casa Real, pelo menos nas mesas de pessoas mais destacadas, fosse de boa qualidade. Havia ainda pães de outros cereais como centeio, cevada, aveia, os quais os camponeses utilizavam com frequiência.

Com pão se faziam também vários pratos: entre esses as sopas -presença marcante nas refeições como se pode ver por meio das tabelas 1 e $2-$ e também diferentes tipos de fatias. As fatias consistiam em uma base de pão coberta com carnes, miúdos ou peixes picados preparados de diversos modos, como indicado no livro de cozinha de Lucas Rigaud, obra publicada cem anos depois da Arte de Cozinha de Domingos Rodrigues. Rigaud era francês e suas receitas revelam uma nova forma de cozinhar introduzida em Portugal, muito provavelmente antes da primeira edição de sua obra em $1780^{57}$. Uma culinária menos condimentada, na qual as especiarias orientais eram usadas com mais moderação, além de novas formas de preparar massas, carnes e doces. No entanto, no século XVII e no XVIII, o pão era o acompanhamento por excelência das carnes. A receita de «perna de carneiro armada» de Domingos Rodrigues informava como esta deveria ser servida:

como estiver cozido, coalhe-se a substância com duas gemas de ovos, $e$ lance-se no prato com fatias de pão por baixo e sumo de limão e canela por cima. Deste modo se faz peru armado, galinha, frangos e pombos ${ }^{58}$.

As sopas, por sua vez, consistiam num tipo de preparado com pouco líquido e eram bem mais pastosas do que aquelas que conhecemos hoje, quase sempre servidas com pão, ou melhor, empapava-se o pão com a sopa. A receita de «sopa de qualquer gênero de assado» do mesmo cozinheiro dá bem idéia da técnica de sua confecção:

Feito um vintém de pão em fatias, ponha-se uma camada delas em uma frigideira grande untada de manteiga, cubram-se de açúcar e canela (...) Deitem-lhe um pouco de caldo de galinha ou de carneiro e deixe-se estufar devagar em pouco lume (...) deitem-lhe uma dúzia de ovos por cima com açúcar e canela (...) tirada da frigideira e posta em um prato, se trinchará o

1 litro. Um arrátel seria o mesmo que 456 gramas. Ver Índice de palavras do Livro de Cozinha da Infanta D. Maria, Lisboa, IN-CM, 1986.

${ }^{57}$ Lucas Rigaud, Cozinheiro moderno ou Nova arte de cozinha, Sintra, Colares Editores, 1999. (1780)

${ }^{58}$ Domingos Rodrigues, op. cit., p. 57. 
assado, que podem ser galinhas ou frangos ou pombos ou perus. Este é um prato ordinário ${ }^{59}$.

O farelo de pão era outra forma de utilização do produto. Usava-se para engrossar caldos e papas e entrava na composição de recheios, como no da receita de «recheio de peixe», no qual se adicionaram aos ovos crus, cebola, peixe picado e cheiros, cinco réis de pão ralado ${ }^{60}$. A ração de pão oferecida aos oficiais da Casa Real poderia, portanto, ser consumida de muitas maneiras. O trigo e outros cereais participavam ainda da dieta das elites na forma de bolos, tortas, pastéis e empadas. Esses pratos elaborados com farinha de trigo ou com centeio eram, possivelmente, as «massas» indicadas no serviço de mesa de alguns segmentos da Casa Real e que não foram especificadas no decreto. Tanto Domingos Rodrigues quanto Lucas Rigaud proporcionaram a seus leitores uma ampla variedade de receitas desse tipo, sinal de que eram apreciadas na época ${ }^{61}$.

Quanto às carnes, além de serem utilizadas nos recheios das massas podiam ser consumidas de muitas formas e consistiam de variadas espécies de caça ou de animais de criação como, javalis, cabritos, lebres, carneiros, vaca e aves distintas e iam à mesa na forma de assados e guisados, conforme assinalado no decreto de D. José I. Seu alto consumo pelas elites era o responsável pela «gota», famosa doença difundida entre a aristocracia, «devido a muita carne e muita comida ingerida» e que «tinha a ver mais com o conformismo social do que com o gosto pessoal dos indivíduos» ${ }^{62}$.

Ao que tudo indica, as carnes de porco e de vitela eram geralmente servidas assadas, enquanto o carneiro poderia ser guisado ${ }^{63}$. Perdizes, pombas e frangas também apareciam com frequiência nas mesas dos oficiais da casa real, sendo que em muitas destas deveria haver uma galinha todos os dias à refeição do meio$\operatorname{dia}^{64}$.

${ }^{59}$ Domingos Rodrigues, op. cit., p.47. Observe-se na mesma receita a presença do açúcar e da canela, os quais proporcionavam o sabor agridoce presente em muitos pratos da época, tendência que se perdeu no livro de Lucas Rigaud, op. cit.

${ }^{60}$ Ver Domingos Rodrigues, op. cit., p. 125.

${ }^{61}$ Ver Ibidem, pp. 109-118 e tortas doces pp. 140-145; Lucas Rigaud, op. cit., pp. 205-221, além de outras receitas doces e salgadas espalhadas pelo mesmo livro.

${ }^{62}$ Massimo Montanari, op. cit., p. 93.

${ }^{63} \mathrm{O}$ decreto de $\mathrm{D}$. José mandava o mestre cozinheiro calcular «quantos arráteis de vaca e de presunto se hão de mandar vir para cada prato de olha das diferentes mesas; o número de arráteis de carneiro ou vitela que há de levar cada flamenga de guisado; quantos arráteis de vitela e lombo de porco para cada prato de assado; número de perdizes ou frangas ou pombos que há de levar cada prato que for ave de pena. Ver Decreto de D. José, op. cit., p. 24v.

${ }^{64} \mathrm{De}$ acordo com o médico de $\mathrm{D}$. João $\mathrm{V}$, «entre as aves tem a galinha o primeiro lugar, porque é bom alimento, assim para sãos como para doentes. Sendo nova é temperada, não é quente nem fria e é úmida; coze-se facilmente, digere-se bem, dá alimento de bom suco e pouco excrementício». Ver Francisco da Fonseca Henríquez, Âncora medicinal para conservar a vida com saúde, (1721), São Paulo, Ateliê Editorial, 2004, p. 115. 
Se cotejarmos as informações presentes no decreto com o conteúdo das receitas disponíveis nos livros e cadernos de cozinha da época, notaremos que diferentes tipos de carnes eram utilizados na confecção da «olha», iguaria de origem espanhola, muito apreciada e recomendada em grande parte das mesas da casa real, especialmente para o almoço (refeição do meio dia intitulada na época de jantar).Vide tabela 1. De acordo com o documento régio, a olha levaria «vaca e presunto» ${ }^{65}$, enquanto Domingos Rodrigues em sua receita de «olha podrida» propôs utilizar: vaca, galinha, adem, perdiz ou pombo, coelho, lebre, um pedaço de pernil de porco, chouriços, lingüiça e lombo de porco. Todas essas carnes em uma única receita dão idéia da quantidade de carne ingerida e de sua importância à mesa. A olha era um prato bem calórico e consistente que levava ainda nabos, rábanos, couves, grãos, duas ou três dúzias de castanhas, sal e cheiros. Quando tudo estivesse pronto mandava-se à mesa «sobre sopas de pão». Se à primeira vista pode parecer singelo oferecer apenas «sopa e olha» a alguns oficiais da Casa Real, frente às receitas de olha do livro de Rodrigues pode-se avaliar um privilégio receber essa iguaria como ração, haja vista a variedade de carnes presente em sua confecção.

Ainda no âmbito das técnicas culinárias, as sopas consumidas por grande parte da população nas três refeições do dia levavam, além das carnes, muitos vegetais. As primeiras, claro, na dependência do orçamento familiar. A julgar pela dieta sugerida para as diversas mesas, bem como pelos menus da época, pode-se pensar que nas mesas da família real pelo menos um dos oito pratos oferecidos fosse de sopa, que geralmente fazia parte do primeiro serviço. De acordo com o almanaque dos gourmands de 1805 ,

Um grande jantar se compõem geralmente de quatro serviços: o primeiro compreende as sopas, os hors-d'oeuvre e as entradas; o segundo os assados e as saladas; o terceiro os patês frios e os entremeios de todo tipo, o quarto de sobremesa, compreende frutas cruas, compotas, biscoitos, macarons, os queijos e toda espécie de bombons e petit four, confeitos e os sorvetes ${ }^{66}$.

A preponderância da carne, enquanto alimento das elites, se expressava não apenas por meio da presença dos assados e guisados. É preciso lembrar que a maior parte das entradas e dos entremeios era à base de carnes. Estas podiam ser cozidas com ou sem molho, abafadas, grelhadas ou fritas. Os assados, porém, compunham a parte central de qualquer refeição ${ }^{67}$, o que explica a importância do trinchante na corte, ou seja, daquele que deveria partir ou trinchar as carnes ${ }^{68}$.

${ }^{65} \mathrm{O}$ decreto manda o mestre cozinheiro calcular quantos arráteis de vaca e de presunto se hão de mandar vir para cada prato de olha das diferentes mesas ver Decreto de D. José, op. cit., p. 25v.

${ }^{66}$ Grimod de La Reynière, Almanach dês gourmands, t. 3, (1805), p. 18. APUD Jean-Louis Flandrin, op. cit., p. 15.

${ }^{67}$ Jean-Louis Flandrin, op. cit., p. 27.

${ }^{68}$ Sobre a importância do trinchante no serviço de mesa, especialmente para o corte das carnes de grandes dimensões ver Marchesi e Vercelloni, op. cit., p. 32. 
Quanto aos demais pratos dos dois serviços da mesa do rei, embora não tenham sido especificados no decreto, o que se pode imaginar a partir de descrições coevas é que pratos de funções diferentes coexistiam em um mesmo serviço $^{69}$. Isto é, era comum servir os entremeios com os assados e saladas ${ }^{70}$, ou os doces junto com os salgados. Por outro lado, como observou o autor de L'Ordre des mets, pode-se até ter idéia dos pratos que compunham um serviço de mesa, mas não sabemos sua ordem de consumo. Por exemplo: o que se ingeria primeiro numa coberta, a sopa ou as entradas frias? O mesmo é válido para a ordem das sobremesas: doces quentes ou doces frios $?^{71}$ Com relação às guarnições, o decreto informava que os assados eram acompanhados com salada e que com guisado se servia arroz ${ }^{72}$. Mas não sabemos se havia outras guarnições, nem qual se comeria antes. No livro de Domingos Rodrigues há poucas referências a legumes e verduras. Geralmente aparecem referidos aos «pratinhos» ou pratos pequenos, cujas receitas eram feitas à base de «ervas» (berinjelas, alcachofras, cenouras, aspargos), ou de «descaídas», isto é, miúdos tais como miolo, rins ou fígado. Havia pratinhos também de peixes e mexilhões nos «dias magros» ${ }^{73}$. E provável que estes fossem os referidos entremeios.

Ainda no que diz respeito aos legumes, além de servidos nas saladas, entravam nas sopas e consistiam no alimento básico das classes menos favorecidas. Quanto às frutas, despontam no serviço de mesa da Casa Real apenas enquanto tipo de alimento, mas ignora-se como seriam servidas, pois poderiam ser cruas ou cozidas em calda na forma de marmeladas. O livro Arte de Cozinha oferecia uma grande variedade dessas receitas em um capítulo dedicado exclusivamente aos doces de frutas ${ }^{74}$.

Por fim, vale lembrar que o Decreto de D. José não mencionava nada sobre os temperos, um segmento importantíssimo da culinária, não apenas devido ao sabor que conferia aos alimentos, mas pela sua função de promover o equilíbrio dos humores que compunham o corpo humano, alterando ou acentuando as propriedades de um determinado alimento. Embora segundo os especialistas a utilização das especiarias na terapêutica ocidental tenha atingido seu auge no século

${ }^{69}$ Sobre a mesa real, ver Decreto de 1765 , pp. 20-21.

${ }^{70}$ Jean-Louis Flandrin, op. cit., pp. 23-24.

${ }^{71}$ Nos menus oferecidos no livro de Domingos Rodrigues os pratos de uma mesma coberta foram numerados o que pode indicar que primeiro se ingeriam os doces quentes, depois os frios e por último as frutas; op. cit., pp. 172-173.

72 No caso do arroz, citado no decreto de 1765 como um dos pratos em muitas das mesas da casa real, cabe lembrar que até o século XVII era um produto raro, o que talvez explique o reduzido número de receitas contendo arroz no livro de Domingos Rodrigues. No caso da receita de «carril para qualquer peixe» aparece como o complemento necessário do peixe. Ver Domingos Rodrigues, op. cit., p. 126.

${ }^{73}$ Sobre a ordem dos pratos e sua composição, ver os menus e receitas apresentados por Domingos Rodrigues, op. cit., passim.

${ }^{74}$ Ver Domingos Rodrigues, capítulo IX, op. cit., pp. 159-161. 
XIII, «foi na forma de galenismo que a medicina greco-romana passou ao Ocidente cristão, dominando a medicina e a farmácia até o século XVII e mantendo ainda uma grande influência mesmo no XVIII ${ }^{75}$. Na farmacologia de Galeno, baseada na fisiologia humoral, a vida era mantida pelo equilíbrio entre os quatro humores: sangue, fleuma, bílis amarela e bílis negra. Cada um desses humores tinha diferentes qualidades (o sangue era quente e úmido; a fleuma fria e úmida; a bílis amarela quente e seca; a bílis negra fria e seca). A doença seria decorrência do desequilíbrio de um desses humores. As alterações eram derivadas dos alimentos, os quais quando assimilados pelo organismo davam origem aos quatro humores ${ }^{76}$. A terapêutica indicada seria corrigir o desequilíbrio com a ingestão de alimentos com qualidades contrárias, sendo que estas poderiam ser atingidas por meio da combinação dos temperos.

As relações entre culinária e terapêutica presentes no universo das especiarias são muito amplas e remontam aos tempos antigos. Há condimentos, como bem apontou Rui Rocha, que não são especiarias, como as ervas aromáticas frescas salsa e coentro. Para este autor, «a distinção entre especiarias e ervas é do domínio do mercado, e não da culinária: aquelas adquirem-se estas apanham-se». Umas são secas, as outras frescas. «Só a idéia de aroma pode, aliás, ligar a cebola, a pimenta e o nardo (que é um perfume)» ${ }^{77}$. Na teoria das quatro qualidades (o quente, o frio, o seco e o úmido), as especiarias do Oriente, surgidas em clima quente, tinham propriedades sutis e modificadoras quando adicionadas aos alimentos, o mesmo sucedendo com as ervas. Assim, o tempero constitui na época moderna, «um conjunto estruturado a ser aplicado a cada prato» e, sem observálo atentamente em uma receita, corre-se o risco de não se identificar as mudanças profundas que ocorreram no tempo e nas diferentes civilizações em termos de concepção de alimentação ${ }^{78}$.

Como chamou a atenção Cristiana Couto, «era tarefa dos cozinheiros conhecerem as propriedades dos alimentos: a pimenta-do-reino, por exemplo, era considerada extremamente seca e quente, assim como as carnes de vaca e a canela; raízes, vegetais, e legumes eram tidos como frios e secos e deveriam ser cozidos, adicionando-se a eles elementos quentes e úmidos» ${ }^{79}$. Ou seja, a técnica de preparação dos alimentos e a forma de temperá-los eram fundamentais para manter a saúde do corpo. Todos esses produtos encontravam-se à disposição do com-

${ }^{75}$ Ibidem, pp. 93-97 e 92.

${ }^{76}$ Ver José Pedro Sousa Dias, op. cit., p. 93.

${ }^{77}$ Rui Rocha, A Viagem dos Sabores, Lisboa, Edições INAPA, 1998, pp. 43 e 44.

${ }^{78}$ Ibidem, pp. 44-45.

${ }^{79}$ Cristiana Couto. Arte de Cozinha, alimentação e dietética em Portugal e no Brasil (séculos XVII e XVIII), São Paulo, SENAC, 2007, p. 59. Sobre a relação entre alimentação e saúde ver também: Leila Mezan Algranti. «Alimentação, saúde e sociabilidade: a arte de conservar e confeitar os frutos (séculos XV-XVIII)», in História, Questões e Debates, dossiê História da Alimentação, Editora da Universidade Federal do Paraná, ano 22, 2005, n. 42, pp. 33-52. 
prador da ucharia de $\mathrm{D}$. José, numa época em que a vida nas cidades era facilitada por uma melhoria no abastecimento causada por uma melhor organização nos transportes ${ }^{80}$.

Mesmo que Lisboa estivesse muito bem localizada em termos das rotas de produtos estrangeiros e da circulação de bens de consumo (o que facilitava o acesso a mercadorias de todo tipo) o decreto de D. José I permite constatar que, no que toca à alimentação, os membros da Casa Real constituíam um conjunto de pessoas altamente privilegiado em termos de padrão de consumo. No extremo oposto da sociedade da época moderna havia um amplo segmento de fugitivos, mendigos, ciganos e aldeões esfomeados, os quais Piero Camporesi retratou com maestria em seu livro $O$ País da Fome ${ }^{81}$. Por outro lado, os conteúdos das tabelas 1 e 2 evidenciam que, apesar da abundância de produtos existente nas mesas da Casa Real, havia uma certa monotonia nos tipos de alimentos preparados. Todos os dias deveria haver: sopa, arroz e assados, um cardápio com características que Roche definiu como «regime repetitivo», cuja regularidade seria quebrada pela dieta dos dias magros e das festividades ${ }^{82}$. Os menus da quaresma no entanto, disponíveis no livro de Domingos Rodrigues, indicam igualmente que havia certas receitas de base (como as denominou Jack Goody) as quais, adaptadas, podiam se multiplicar em variações de um mesmo prato ${ }^{83}$. Em outras palavras, nota-se por meio das receitas disponíveis na Arte de Cozinha e no texto do decreto de D. José, que havia estruturas fundamentais de cozinha reproduzidas há muito tempo em Portugal que foram sendo aplicadas, integralmente ou modificadas, de acordo com as necessidades dos indivíduos, a disponibilidade nas despensas e as influências de outros povos ${ }^{84}$.

O decreto de 1765 , referente à Ucharia real e o próprio teor normativo que ele continha, nos levou a refletir sobre a ritualização das ações cotidianas na corte portuguesa da época, onde todos os gestos eram previstos e observados, impondo-se normas de convivência e sociabilidade. Mas mais do que isso, a divisão dos membros da Casa Real em mesas distintas, além de reforçar a hierarquia social, apontou para as relações sociais e de poder que o partilhar de uma mesma mesa impunha.

No que se refere à oferta de comida, nota-se que esta significava mais do que produtos ingeridos ou tecnicamente processados e comercializados. Comida

${ }^{80}$ Daniel Roche, op. cit., p. 303.

${ }^{81}$ Piero Camporesi, El país del hambre, trad., México, Fondo de Cultura, 1997.

${ }^{82}$ Sobre a monotonia dos menus ver Daniel Roche, op. cit., p. 302.

${ }^{83}$ Ver Jack Goody, «Receita, prescrição, experimentação», in Domesticação do Pensamento Selvagem, Lisboa, Editorial Presença, 1988, p. 157.

${ }^{84}$ Sobre o intercâmbio e as influências estrangeiras na culinária portuguesa ver Isabel Drumond Braga «Influências estrangeiras nos livros de cozinha portugueses - séculos XVI-XIX alguns problemas de análise», in Do primeiro almoço à Ceia - estudos de História da Alimentação, Sintra, Colares Editora, 2004, pp. 101-110. 
nesse contexto era graça, remuneração, dádiva e objeto de caridade ou magnificência do rei. Nesse amplo campo simbólico que a alimentação e seus rituais apresentam para o estudo da vida em sociedades nas quais as aparências contavam muito, havia também, conforme este estudo procurou destacar, um universo material que contribuía para a conquista da distinção social. O lugar à mesa, o que era servido (número e tipos de pratos), a louça e as baixelas demarcavam posições sociais e propiciavam a obtenção de prestígio e reconhecimento. Não à toa tudo isso era regulado por decretos e leis sunptuárias que investiam os bens e artefatos de sentidos construídos e compartilhados pelos e para os membros daquela sociedade. Como bem formulou Pierre Bourdieu, será o reconhecimento, portanto, que concretizará o poder simbólico de certos bens ${ }^{85}$.

${ }^{85}$ Pierre Bourdieu, O poder simbólico, trad., Rio de Janeiro, Bertrand Brasil, 2003, p. 37. Para uma análise semelhante e muito inspiradora ver Camila Borges da Silva $O$ Símbolo indumentário: distinção e prestígio no Rio de Janeiro (1808-1821), diss. de mestrado, Rio de Janeiro, UERJ, 2009. 